\title{
Review
}

Frithjof C. Küpper* and Nicholas A. Kamenos

\section{The future of marine biodiversity and marine ecosystem functioning in UK coastal and territorial waters (including UK Overseas Territories) - with an emphasis on marine macrophyte communities}

https://doi.org/10.1515/bot-2018-0076

Received 13 August, 2018; accepted 23 October, 2018; online first 20 November, 2018

\begin{abstract}
Marine biodiversity and ecosystem functioning including seaweed communities - in the territorial waters of the UK and its Overseas Territories are facing unprecedented pressures. Key stressors are changes in ecosystem functioning due to biodiversity loss caused by ocean warming (species replacement and migration, e.g. affecting kelp forests), sea level rise (e.g. loss of habitats including salt marshes), plastic pollution (e.g. entanglement and ingestion), alien species with increasing numbers of alien seaweeds (e.g. outcompeting native species and parasite transmission), overexploitation (e.g. loss of energy supply further up the food web), habitat destruction (e.g. loss of nursery areas for commercially important species) and ocean acidification (e.g. skeletal weakening of ecosystem engineers including coralline algal beds). These stressors are currently affecting biodiversity, and their impact can be projected for the future. All stressors may act alone or in synergy. Marine biodiversity provides crucial goods and services. Climate change and biodiversity loss pose new challenges for legislation. In particular, there are implications of climate change for the designation and management of Marine Protected Areas and natural carbon storage by marine systems to help control the global climate system. The UK currently has legal obligations to protect biodiversity under international and European law.
\end{abstract}

Keywords: alien species; biodiversity loss; climate change; ecosystem services; legislation; mangroves;

\footnotetext{
*Corresponding author: Frithjof C. Küpper, School of Biological Sciences, University of Aberdeen, Cruickshank Building, St Machar Drive, Aberdeen AB24 3UU, Scotland, UK; and Marine Biodiscovery Centre, Department of Chemistry, University of Aberdeen, Aberdeen AB24 3UE, Scotland, UK, e-mail: fkuepper@abdn.ac.uk

Nicholas A. Kamenos: School of Geographical and Earth Sciences, Gregory Building, University of Glasgow, Glasgow, G12 8QQ,

Scotland, UK
}

overexploitation; seabirds; seagrasses; seaweeds; sea level rise.

Dedicated to: Dr. Susan Loiseaux-de Goer (Roscoff) on the occasion of her 80th birthday (Aug. 5, 2018).

\section{Introduction}

\section{Global trends and stressors affecting marine biodiversity and marine ecosystem function- ing worldwide}

The global marine environment is currently undergoing unprecedented change at multiple levels due to multiple stressors including climate change, overfishing, eutrophication, colonization by alien species, habitat destruction (e.g. by coastal developments) and marine litter. Biodiversity loss rarely occurs on its own, but it is usually a consequence of drivers acting either alone or in synergy. The purpose of this review is to summarize the current state of scientific knowledge on biodiversity loss, climate warming and ocean acidification, especially for the coastal and territorial waters of the UK, and the relevance and impacts of these developments for the UK's society and economy - however, it should be highlighted that most of the issues discussed here are global.

Globally, the marine Living Planet Index (LPI) shows a $49 \%$ decline in populations of marine mammal, bird, reptile and fish species between 1970 and 2012, highlighting dramatic biodiversity loss (WWF 2015). Climate change and other forms of environmental change also pose new challenges to legislation. For example, the network of Marine Protected Areas (MPAs) in UK waters was in some cases designed around some localized features which are potentially vulnerable to climate change, meaning that the on-going utility of MPAs as a conservation tool could be affected (MCCIP 2015). A general challenge for assessing most types of such change affecting the distribution and abundance of living organisms in the 
marine environment is the shortage or complete lack of historic baseline data to assess environmental change, which has been termed the "shifting baselines concept" (Jackson et al. 2001, Knowlton and Jackson 2008).

\section{Current trends and effects on UK interests}

Key stressors currently impacting marine life in UK waters are (1) biodiversity loss, (2) ocean warming due to climate change, (3) overexploitation (in particular, overfishing) of certain target species affecting the food web, (4) plastic pollution and (5) alien species.

\section{Biodiversity loss and implications for ecosystem functioning}

Little knowledge exists about overall biodiversity loss in UK waters but significant range shifts are ongoing mostly due to climate change, which are expected to be compounded in the next decades by ocean acidification (see below). Globally, climate change alone is predicted to result in dramatic species turnovers of over $60 \%$ of the present biodiversity, implying ecological disturbances that potentially disrupt ecosystem services (Cheung et al. 2009b). Studying sedimentary, soft-bottom systems in the UK's North Sea, a recent study into the links between changes in benthic biodiversity and ecosystem functioning (Frid and Caswell 2015) found that the relationship is idiosyncratic, but a degree of temporal stability in functioning is maintained such that the ecosystem services which such soft-bottom systems underpin would also be stable during decadal and longer-term changes. Further implications for marine carbon storage are discussed below.

\section{Ocean warming due to climate change}

The North Atlantic Current (Gulf Stream) creates a climatic anomaly by providing a more temperate climate than what would be expected at the UK's latitude. This, in turn, is a determining factor for the biodiversity found in the North Atlantic and therefore around the UK and Western Europe. The North Atlantic Current is part of the Atlantic Meridional Overturning Circulation (AMOC), abrupt changes of which have long been hypothesized to be a central driver for the onset and end of ice ages (Henry et al. 2016). Any change to the AMOC system and, consequently, rapid climate change, would have profound implications for both the terrestrial and maritime climatic conditions of the UK. Consequently, this has received considerable attention for the public.

While, at present, long-term changes impacting the UK are not detectable (McCarthy et al. 2015), the North Atlantic Current demonstrates the importance of ocean temperature for determining marine biodiversity. Ocean temperature is projected to rise by between $1.2^{\circ} \mathrm{C}$ and $3.2^{\circ} \mathrm{C}$ by 2100 , depending on greenhouse gas emissions (Genner et al. 2017). However, an increased frequency of marine heatwaves is clearly detectable, as much in UK and European waters as worldwide (Oliver et al. 2018). Global average marine heatwave frequency and duration increased by $34 \%$ and $17 \%$, respectively, resulting in a 54\% increase in annual marine heatwave days globally. Importantly, these trends can largely be explained by increases in mean ocean temperatures, suggesting that further increases in marine heatwave days under continued global warming can be expected.

This is likely to have a number of effects, depending on future climate change scenarios, including on species distributions (Cheung et al. 2009b). For example, in the North Sea and on the Scottish west coast, a survey of $>300$ fish species has revealed that taxa with southern biogeographic affinities have increased in abundance since the mid-1990s (Beare et al. 2004), with trawl data suggesting that the North Sea is experiencing waves of immigration by exotic, southern species (e.g. red mullet, anchovy and pilchard). For marine macrophytes, a recent review of 42 studies (King et al. 2018a) found clear differences in thermal niche between geographically separated populations, suggesting that non-trailing edge populations may also be vulnerable to future warming trends and, given their limited dispersal capacity, such population loss may not be offset by immigration. It also highlighted how next generation sequencing (NGS) is allowing unprecedented mechanistic insight into plasticity and adaptation, in particular in the context of climate change-related impacts.

In Australian temperate reef communities, rapid climate-driven regime shift has resulted in loss of their defining kelp forests and replacement by persistent seaweed turfs (Wernberg et al. 2016). After decades of ocean warming, extreme marine heat waves forced a $100-\mathrm{km}$ range contraction of extensive kelp forests and saw temperate species replaced by seaweeds, invertebrates, corals, and fishes characteristic of subtropical and tropical waters. This community-wide tropicalization fundamentally altered key ecological processes, suppressing the recovery of kelp forests.

Ocean warming will interact with other stressors, such as ocean acidification and increased storminess, which are well documented in UK and European seas 
(Mackenzie and Schiedek 2007). The exact extent of the impacts is difficult to project as the specific combinations of stressors over the coming century are not yet known, but could be significant. For example, the combined impacts of these stressors may cause structurally diverse seaweed canopies, which are habitats to a wide range of flora, to be replaced by less diverse habitats dominated by non-calcified, turf-forming seaweeds (Brodie et al. 2014).

\section{Overexploitation}

Overexploitation (in particular, overfishing) is threatening many marine vertebrates - particularly large vertebrates and top predators such as tunas and sharks, which have seen large declines (Baum et al. 2003) - with UK waters being no exception from this global trend. A topical review about the impact of ocean warming on sustainable fisheries management has recently been published (Serpetti et al. 2017). After the collapse of the populations of large whales, whaling is currently only conducted by very few countries in limited areas and is no longer an issue in territorial waters of the UK and its Overseas Territories. Nevertheless, overfishing of certain target species at low trophic levels can also substantially affect the ecosystem, especially when such species constitute a high proportion of the biomass or are highly connected in the food web (Smith et al. 2011). In UK waters, cod and sand eel stocks have particularly suffered overexploitation. The latter case has had serious impacts on seabird populations (Frederiksen et al. 2013) - with the impact being compounded by the synergy of sand eel overfishing and the range shift of the copepod Calanus finmarchicus, a main food species of sand eel (see Seabird section below). In the case of cod, the combination of intense fishing pressure and climate change (discussed above) has led to a northward shift of distribution ranges (Engelhard et al. 2014). In the territorial waters around the Falklands and South Georgia, the management of the Patagonian toothfish stock is a good example of sustainable management of a species that has only recently received major commercial interest, resulting in a strongly expanded fishery (Collins et al. 2010). Wild seaweed stocks are currently not exploited at an industrial scale in UK waters.

\section{Plastic and nanoparticle pollution}

Plastic and nanoparticle pollution, both by large items such as fishing gear and the microscopic particles resulting from physical and chemical breakdown, has emerged as a major environmental issue affecting the world's oceans (Andrady 2011) and the UK's coasts and territorial waters are no exception from this (e.g. Gallagher et al.2016, Horton et al. 2017). Plastic particles may directly impact marine animals by ingestion, mistaken for food particles, and subsequent choking of the digestive system, but also by entanglement leading to injury, drowning etc., and as absorbents of pollutants (Gregory 2009). They can also act as vectors of marine life, which may greatly increase the odds of alien species transfers (Barnes 2002, Gregory 2009). Significantly, sewage treatment plants of current design are not capable of eliminating significant inputs of microplastic pollution into freshwater and marine water bodies (Mason et al. 2016). Nanoparticles are a facet of this issue, the environmental impacts of which have received research interest only in recent years. Especially silver nanoparticles, which are finding increasingly wide applications from water treatment to textiles, have been found to impact plankton communities at all levels - including severe growth inhibition of cyanobacteria and eukaryotic phytoplankton, and significant changes of bacterial community composition (Burchardt et al. 2012, Doiron et al. 2012, Bielmyer-Fraser et al. 2014, Das et al. 2014, Baptista et al. 2015, Tsiola et al. 2018).

\section{Invasive alien species}

Invasive alien species are considered a major threat to biodiversity, especially in synergy with other drivers of change (Roy et al. 2014). The UK's waters are not exempt from the arrival of alien marine species. A recent review (Roy et al. 2014) lists and ranks 52 alien species, of which 8 are considered invasive, with the majority of them originating from Asia. Impacts on native species can be due to predation/herbivory, competition, transmission of parasites and pathogens to native species, and genetic effects. In this study (Roy et al. 2014), the quagga mussel, Dreissenia rostriformis bugensis, received maximum scores for risk of arrival, establishment and impact on native biodiversity, followed by two Asian-origin shore crabs (Hemigrapsus sanguineus, Hemigrapsus takanoi), American lobster (Homarus americanus) and American comb jelly (Mnemiopsis leidyi). A recent review lists 17 documented alien seaweeds in UK waters (Minchin et al. 2013), namely the brown algae Colpomenia peregrina, Undaria pinnatifida and Sargassum muticum, the red algae Antithamnionella spirographidis, Antithamnionella ternifolia, Asparagopsis armata, Bonnemaisonia hamifera, Caulacanthus ustulatus, Heterosiphonia japonica, Pikea californica, Polysiphonia harveyi, Cryptonemia hibernica, Grateloupia subpectinata, 
Grateloupia turuturu, Sarcodiotheca gaudichaudi and Solieria chordalis, and the green alga Codium fragile ssp. fragile. Roy et al. (2014) consider the red alga Gracilaria vermiculophylla, which is not permanently established in UK waters yet, as a high-risk species with respect to likelihood of arriving, establishing and having an impact on native biodiversity in Britain over the next ten years. The same study ranks the red algae Aglaothamnion halliae and Antithamnion pectinatum as well as the green alga Caulerpa taxifolia as posing a medium risk in the same context.

\section{Ocean acidification}

Ocean acidification, by its physicochemical nature impacting the carbonate-bicarbonate equilibrium, primarily affects calcifying organisms. In UK waters, these include marine molluscs occurring in large beds such as blue mussels (West et al. 2016) and horse mussels (below), as well as coralline red algae (see below) and cold-water corals (Roberts et al. 2006). Physiological studies of the cold-water coral Lophelia pertusa have revealed a complex response pattern to increased acidity and $\mathrm{CO}_{2}$ (Hennige et al. 2015).

\section{Sea level rise}

Sea level rise projections by 2100 range between $0.2 \mathrm{~m}$ (Alley and Joughin 2012) and $2 \mathrm{~m}$ (Alley and Joughin 2012), with regional differences (Willis and Church 2012). This is attributed to a combination of ice sheet/glacier melt, thermal expansion of sea water, and the balance between melting, snowfall, and the regular outflow of glaciers from the ice sheets (Willis and Church 2012). This has major implications for the UK as an island nation and its Overseas Territories. Low-lying estuarine areas are at particular risk, including the Greater London conurbation. Some areas of the UK have suffered particularly damaging surge events, and the Firth of Clyde is a region with high risk due to its location and morphology, even more so with the prospect of global sea level rise (Sabatino et al. 2016). Salt marshes are important coastal habitats with major roles in blue carbon storage (see below), as nurseries for marine species and as bird habitats. Interestingly, the elevation of salt marshes can also increase with rising sea levels and, thus, at least partially mitigate rising levels which gives them particular importance in the context of climate change adaptation of the UK (Reef et al. 2017). In the coastal zone, sea level alterations are measured by a combination of satellite altimetry and tide gauges (Cipollini et al. 2017).

\section{Case studies}

We have identified the following taxonomic and functional groups as exemplary, however, it is important to note that the consequences of these stressors will vary depending on which taxonomic group is considered.

Seaweed beds are an iconic example for the marine biodiversity of the UK and its Overseas Territories and the changes and threats that it faces. Seaweeds provide significant habitats to marine organisms in UK waters. Large brown seaweeds, kelps (Laminariales) and wracks (Fucoids), are major structuring elements on rocky shores of the UK, forming large intertidal or subtidal, forest-like communities. Kelp forests in the UK represent a significant carbon stock, play a key role in energy and nutrient cycling in inshore waters and provide food and habitat for a wealth of associated organisms, including socioeconomically important species (Smale et al. 2016). Such seaweed forests are important as nurseries for a plethora of marine animals including commercial fish and shellfish species, for coastal protection (Bartsch et al. 2008), and for coastal atmospheric/climatic processes (e.g. cloud formation as a consequence of iodine emissions; Küpper et al. 2011). In addition, the UK has significant quantities of calcifying seaweeds (called maerl or coralline algae) found primarily on the south, west and north coasts (van der Heijden and Kamenos 2015a). These contrast to the fleshy seaweeds since coralline algae have a calcium carbonate skeleton, meaning they may be more sensitive to ocean acidification (Yesson et al. 2015).

Seaweed distribution in UK waters has undergone significant changes in recent decades; this is associated with changing sea surface temperatures, which have led to significant declines in the south for kelp species and increases in northern and central areas for some kelps and wracks (Yesson et al. 2015). A recent review (Brodie et al. 2014) has covered potential changes in different vegetation communities of the North Atlantic, predicting that warming will kill off kelp forests in the south and that ocean acidification will reduce coralline algal created habitat in the north. More specifically, the southern kelp species Laminaria ochroleuca is expected to proliferate on the Channel Coast, increasingly replacing Laminaria digitata and Laminaria hyperborea. Indeed, surveys have confirmed that the replacement of $L$. hyperborea by $L$. ochroleuca has started on the Channel Coast, with results suggesting that local biodiversity patterns and ecological processes (e.g. timing of productivity and trophic pathways) on shallow subtidal reefs may be altered by shifts in the relative abundances of habitat-forming kelp species (Smale et al. 2015). More recent work showed that the 
substitution of L. hyperborea by L. ochroleuca as a habitat-forming species can lead to impoverished communities (Teagle and Smale 2018) and reduced resilience of kelp canopies to wave and storm action (Smale and Vance 2016). A physiological study predicts that $L$. ochroleuca may be released from its summer cold limit in winter but still be prevented from moving up the shore due to desiccation in the summer. Laminaria ochroleuca will, however, likely be able to move into tidal pools (King et al. 2018b). Endophytic algae are an important aspect of kelp ecology, but very little is known about this in the context of global change (Eggert et al. 2010). Seagrasses are expected to proliferate in west and north European waters (summarized in Figure 1; Yesson et al. 2015). While there is evidence that maerl-forming coralline algae may initially persist in the future under ocean acidification, the carbon rich deposits they create (composed of dead algae) may dissolve (Brodie et al. 2014, van der Heijden and Kamenos 2015a) and they may be outcompeted by faster growing fleshy seaweeds (Kroeker et al. 2013).

Fish stocks and, consequently, fisheries resources in the territorial waters of the UK and its Overseas Territories are being profoundly impacted by climate change. It is well documented that climate change is leading to distribution shifts in marine fishes in UK waters (Perry et al. 2005) - in particular, species with southern affinities have been strongly expanding in the North Sea since the 1990s (Beare et al. 2004). Overall, the species richness of the fish fauna seems to increase because of climate change (Hiddink and ter Hofstede 2008), while key species such as cod are declining in UK waters and shifting their range northwards towards Arctic waters (Clark et al. 2003, Blanchard et al. 2005). Globally, a survey of 132 national economies revealed that many of the world's poorest countries are particularly vulnerable to climate change-induced impacts of climate change on fisheries (Allison et al. 2009).

Cold-water coral reefs are fragile, rich and long-lived ecosystems, which are particularly significant in the area of the continental margin and offshore sea mounts of the UK and neighboring international waters (Roberts et al. 2006). They face double human impacts from bottom trawling, which can damage these fragile structures, and increasing ocean acidity, which together may have devastating consequences (Roberts and Cairns 2014).

Filter feeders have a major role in the functioning of the UK's seabed ecosystems. In this context, an important community, horse mussel beds (Modiolus modiolus), currently appear as a designated feature in ten Marine Protected Areas. They form beds and reefs which stabilize the seabed, creating a home for many other creatures and good feeding grounds for young fish. Bottom trawls and dredges, particularly those used for scallops, are known to have caused widespread and long-lasting damage to some horse mussel beds. Based on modelling projections, it is feared that this feature will no longer be present in the UK network of MPAs by 2100 due to rising sea temperatures (Gormley et al. 2013).

The UK's coasts are home to large and iconic seabird populations, which occupy high levels in coastal food webs. Major changes are expected for the UK's seabird fauna. The puffin (Fratercula arctica), tourist magnets e.g. of the Shetland Islands for example, has been declining in the UK and beyond (Frederiksen et al. 2013). This is strongly correlated with the climate-related decline of a major copepod species, Calanus finnmarchicus constituting the basis of the food web that puffins and other seabird species rely on (Frederiksen et al. 2013). Conversely, the little egret (Egretta garzetta), not recorded as a breeding bird until 1997 and considered a species with warm-temperate affinities, has recently strongly expanded its range into the UK (Wood and Stillman 2014, MCCIP 2015).

Marine storage of organic carbon, also called blue carbon, is the organic carbon stored in coastal and marine ecosystems. Seagrass meadows, salt marshes and mangroves have long been recognized as major players in marine carbon burial due to the deposition of organic carbon in their biomass (Krause-Jensen et al. 2018). While this body of literature has been growing globally, little has been published with a specific scope on UK territorial waters. The scope here will be on seagrass meadows, coralline red algal communities and seaweeds (macroalgae) - and the expectable changes due to human stressors. Seagrasses are ecosystem engineers in seabed communities in many tropical to temperate seas of the world (Waycott et al. 2006). Besides having major roles as shelters and nurseries (Ermgassen et al. 2016), seagrass communities are highly significant for benthic carbon sequestration (Trevathan-Tackett et al. 2015) and their decline has been implicated in loss of carbon storage capacity (Marba et al. 2015, Mazarrasa et al. 2017a,b). Conversely, revegetation by seagrass cover can reestablish benthic storage capacity (Marba et al. 2015). Future fleshy-macroalgal derived carbon burial may increase as waters warm and $\mathrm{CO}_{2}$ concentrations increase causing increased macroalgal biomass over the coming century, although the exact impact of multiple stressors still remains uncertain (Brodie et al. 2014). While the role of coralline algal deposits in carbon burial is beginning to be recognized (van der Heijden and Kamenos 2015b), this is only recent and a better understanding exists for the role of non-coralline macroalgae in this 
Present day
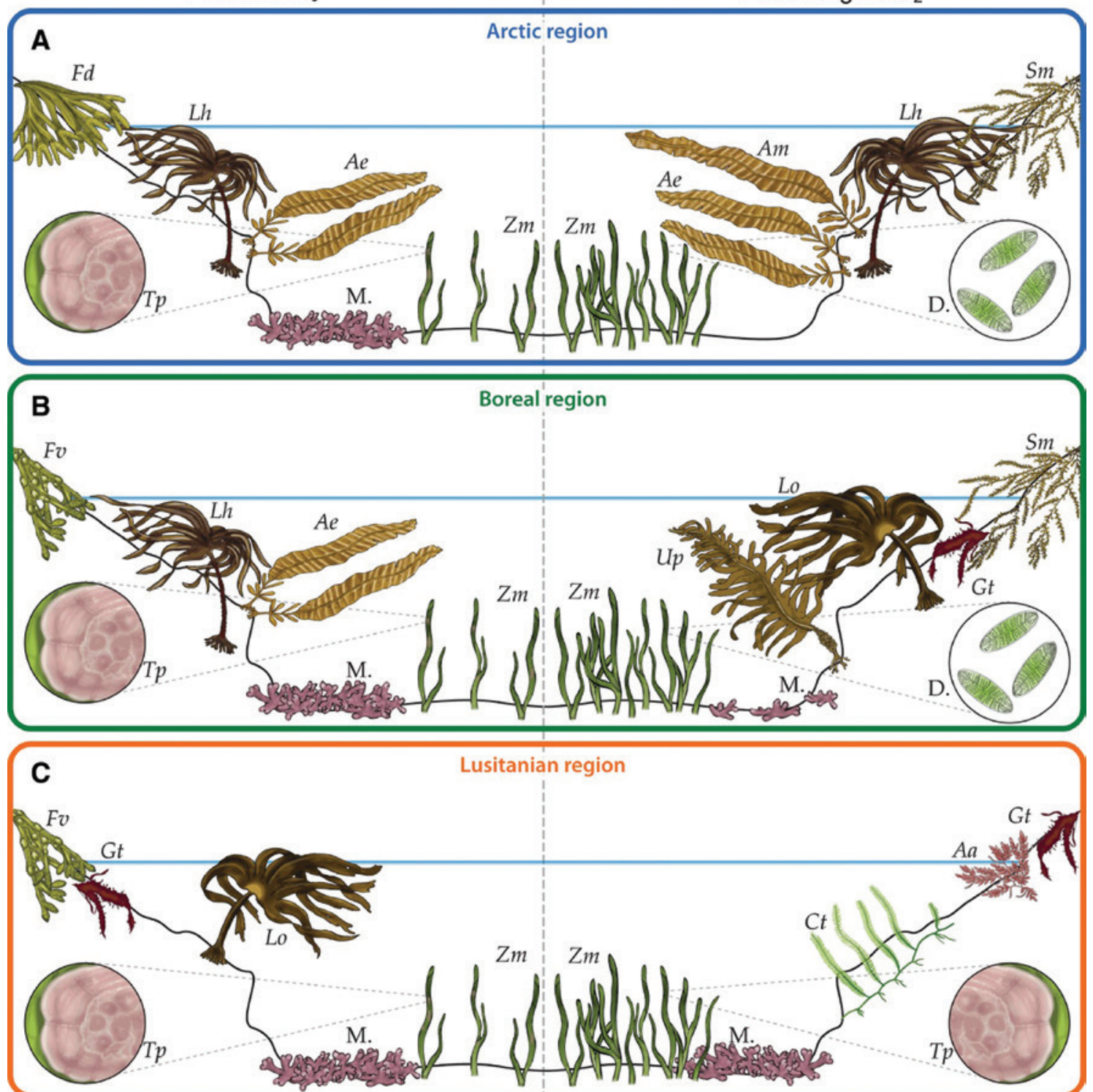

Lusitanian region
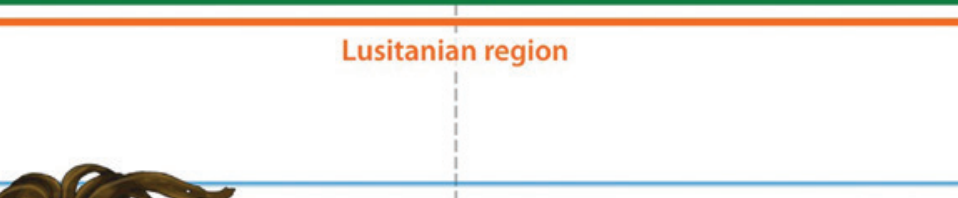


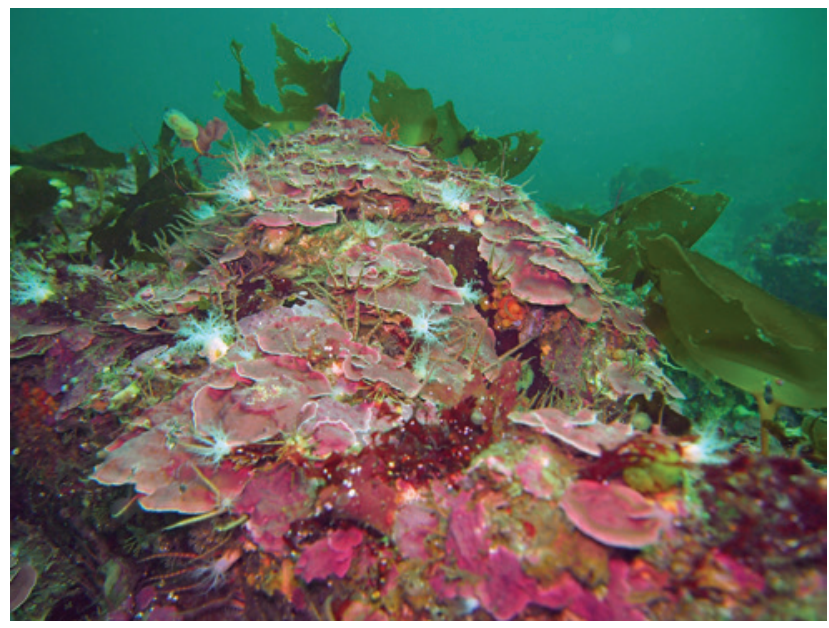

Figure 2: Coralline algae at the lower limit of kelp forest at approx. Twenty meter depth, Port William, East Falkland (FCK, Feb. 2013).

\section{UK Overseas Territories}

Overall, the 14 UK Overseas Territories are subject to all of the drivers of change discussed above, in varying degrees depending on their location. Key issues in the context of this review include climate change, biodiversity loss, and alien/invasive species. The coastal and maritime areas of UK Overseas Territories are large. While the European UK has an Economic Exclusion Zone of $773,676 \mathrm{~km}^{2}$, that of all UK Overseas Territories is $6,031,910 \mathrm{~km}^{2}$ (National Archives 2013).

While the UK is entirely located in the cold-temperate North Atlantic, UK Overseas Territories represent diverse climate zones and biomes from polar to tropical - from the Antarctic to the Equator. Many of these areas have had moderate or virtually no local human impact so far and constitute prime wilderness areas. To some extent, the high conservation value of these areas has been recognized by the creation of very large MPAs e.g. around the British Indian Ocean Territory (BIOT; Sheppard et al. 2012) or, most recently, the proposal for the creation of a large MPA around Ascension Island. Similar to our recent work in the southwestern Antarctic Peninsula (Mystikou et al. 2014) or the Canadian Arctic (Küpper et al. 2016), scientists monitoring environmental change in most if not all UK Overseas Territories are likely confronting the shifting baselines problem (Jackson et al. 2001, Jackson 2008, Knowlton and Jackson 2008), i.e. due to the lack of reliable datasets of community composition prior to the onset of major environmental change, it may be difficult to assess the impacts of the change on the community in question. Recent studies (Asensi and Küpper 2012, Tsiamis et al. 2013) have highlighted the value of historic datasets in assessing the changes in seaweed-dominated coastal ecosystems.

Compared to other UK Overseas Territories, the marine biodiversity and inshore ecology of Ascension Island has been relatively well-studied. A synopsis is provided by the papers stemming from the 2012 Painted Shrimp Expedition led by the South Atlantic Environmental Research Institute (SAERI; Brickle et al. 2017). In comparison to the above, much less - if any - knowledge exists for other UK Overseas Territories such as Pitcairn, Anguilla or the BIOT. However, as UK trends appear to be reflected globally (van der Heijden and Kamenos 2015a), indications are the that UK Overseas Territories will face similar threats to their biodiversity.

Climate change is the major issue confronting biodiversity in UK Overseas Territories at higher latitudes. Antarctic marine species have been found to have extreme sensitivity of biological function to temperature (Peck et al. 2004). South Georgia is unique in many respects and particularly worth mentioning. Located at the Antarctic Convergence, biota include many taxa which are at their northern range limit (Antarctic species) but also numerous endemics as well as cold-temperate species which are at the southernmost range limit. Antarctic species and endemic species in South Georgia will likely come under increased pressure in South Georgia with progressing climate change (Hogg et al. 2011). In the same context, the Falkland Islands are significant for large breeding populations of penguins and seals, including the largest breeding population of gentoo penguins (Pygoscelis papua) in the world. Population variability of the latter has been found to be driven by climate (Baylis et al. 2012). Increasing heat episodes are having a toll on recruitment of non-burrowing penguin species (especially gentoos). The Falklands are also home to a very rich marine flora, with very large stands of giant kelp (Macrocystis) and expansive coralline algal reefs (Figure 2). Overall, the flora still has to be considered underexplored in the light of the many new records of algal taxa from recent work and numerous more expected to come (Mystikou et al. 2016).

Maerl beds and calcifying algae are likely of high importance in several UK Overseas Territories, but their extent, biodiversity and role in ecosystem functioning are very much unexplored. They should clearly be a priority for research and conservation in these areas. Around Ascension Island, both non-geniculate coralline red algae and maerl are the major reef builders, where corals are almost completely absent (Price and John 1978, Price and John 1980, Tsiamis et al. 2017). Likewise, extensive coralline red algal beds are common in the hard-bottom understory of the kelp forest around the Falklands (see Graphical Abstract), but little more is known about them. 
Mangroves occur in the UK Overseas Territories of Anguilla, Bermuda, Montserrat, the British Virgin Islands, the British Indian Ocean Territory, and the Turks and Caicos Islands. Mangroves have paramount importance for coastal protection, as nurseries, and for carbon sequestration. Their conservation significance in these territories has long been recognized (Bacon and Alleng 1992). Especially in Bermuda, mangroves have been the subject of several studies (Pfingstl et al. 2014, Pellerin et al. 2015, Outerbridge et al. 2017, Wolsak et al. 2018). A study in Bermuda reports an association of a mangrovedwelling mite with the epiphytic alga Microspora sp. (Chlorophyceae; Syamjith and Ramani 2013), and another investigates the value of mangroves and seagrass beds as fish nurseries (Huijbers et al. 2008). There is concern about mangrove retreat in Bermuda in the context of rising sea level (Ellison 1993). Mangroves in the Turks and Caicos Islands have been used in the context of developing remote sensing techniques for this habitat type since the 1990s (Green et al. 1998a,b).

Coral reefs in Bermuda have received some attention with respect to their ecosystem value (average \$722M USD pa; Sarkis et al. 2010). While the total economic valuation of Bermuda's coral reefs does not contain all goods and services, it does include tourism (\$405.9M USD pa), coastal protection (\$265.9M USD pa), recreation/cultural (\$36.5M USD pa), amenities (\$6.8M USD pa), fisheries (\$4.9M USD pa) and research/education (\$2.3M USD pa). The total economic value of Bermuda's coral reefs is estimated to constitute 12\% of Bermuda's GDP (Sarkis et al. 2010). In the Turks and Caicos Islands, coral reefs were estimated to contribute \$47M USD pa largely from tourism (\$18.2M USD pa), fisheries (\$3.7M USD pa), coastal protection (\$16.9M USD pa) and biodiversity (\$4.7M USD pa), constituting 7.8\% of GDP (Carleton and Lawrence 2005).

In marine systems, alien/invasive species seem to be much less studied in UK Overseas Territories than in their terrestrial systems. For the Falkland Islands and Ascension, very few alien marine species have been recorded, with no obvious, major impact. In contrast, in the Overseas Territories in the Caribbean (Anguilla, Montserrat, the British Virgin Islands and the British Cayman Islands), the invasive, omnivorous lionfish is having major, detrimental impacts (Rocha et al.2015, Hixon et al. 2016). As a predator, it overconsumes native, ecologically important species, in particular in coral reef systems. In numerous cases, invasive mammalian predators on land continue to severely impact native seabird populations (Hilton and Cuthbert 2010). Priority islands for conservation action against mammalian predators include Gough (which according to one published prioritization scheme is the highest-ranked island in the world for mammal eradication), St. Helena and Montserrat, but also on Tristan da Cunha, Pitcairn and the Falkland Islands (Hilton and Cuthbert 2010). One of the few studies covering alien seaweeds in UK Overseas Territories mentions the brown alga Cystoseira compressa and the filamentous red alga Womersleyella setacea, which is considered one of the worst marine invasive species worldwide (Schneider and Lane 2007)

Ocean acidification can be expected to have a major impact in seabed ecosystems of UK Overseas Territories in the future, given the high importance of calcifying organisms (especially coralline algae and corals). Analogous to the UK's territorial waters in Europe, this process will likely be more pronounced at higher latitudes (in particular, in the British Antarctic Territory, South Georgia and the Falkland Islands) than towards the Equator.

In recent years, the Caribbean has been marked by mass coral mortality due to bleaching (loss of algal symbionts; e.g. Eakin et al. 2010, Alemu and Clement 2014), and the UK Overseas Territories in this region are no exception to this. Loss of coral reefs and their replacement by turf algal-dominated communities constitutes a significant phase shift and major loss of biodiversity in the areas affected. This is widely accompanied by a decline in reef fish abundance (Paddack et al. 2009).

\section{Consequences of biodiversity loss for UK interests}

UK marine biodiversity may be worth up to $\sim £ 2670$ billion to the UK (Beaumont et al. 2006) including the services it provides. This figure was calculated based on 2002-2004 valuation of goods and services provided to the UK; those valuations were determined using the total economic valuation framework data derived from peer reviewed literature, Defra Sea Fisheries Statistics 2004, European Parliament Report 2004 and Hebridean Whale and Dolphin Trust (Beaumont et al. 2008). These services include: food provision, raw materials, leisure and recreation, resilience and resistance, nutrient cycling, gas and climate regulation, bioremediation, disturbance prevention and alleviation, cultural heritage, cognitive values (e.g. information used in education and medicine), and biologically mediated habitats (habitat created by living organisms which other organisms use e.g. seagrass and coralline algae; (Beaumont et al. 2008).

At present, there is a paucity of consistent quantitative data available to assess the exact projected loss in biodiversity due to particular aspects of climate change (Ramírez et al. 2017); this is especially true for 
the impacts of services we discuss below. However, as a guide, meta-analysis approaches suggest species turnovers of up to $60 \%$ implying ecological disturbances that may disrupt ecosystem services (Cheung et al. 2009a). Significantly, biodiversity hotspots often occur in the areas most affected by projected climate change; in particular, biodiversity changes in the North Sea will likely respond most to increasing sea surface temperatures (Ramírez et al. 2017). For context in terrestrial systems climate change induced biodiversity losses are expected to cause $15-37 \%$ of species being committed to extinction (Thomas et al. 2004) with worst case scenarios even leading to possible large scale species extinctions (Bellard et al. 2012).

Here we focus on some of the consequences of stressdriven changes in biodiversity with particular focus on the loss of the carbon storage capacity by marine systems which is facilitated by their high biodiversity.

- Carbon storage: Carbon storage falls within nutrient cycling in many assessments of carbon's role in ecosystem service provision. For example, marine nutrient cycling provides £2320 billion of ecosystem services in the form of nutrients available for life and also those that increase marine productivity (i.e. making nutrients available to all levels of the food chain where they are required for the survival of marine organisms; Beaumont et al. 2006). It is only recently that the value of blue carbon has been recognized with marine vegetated systems, including seagrass communities, salt marshes and coralline algal beds, being important in organic carbon burial due their own biomass or that of other organisms associated with them (van der Heijden and Kamenos 2015a). Thus, at present, little research exists on its valuation in the UK. However, its scope is highly significant, for example, around half the carbon that enters the oceans $(-80 \%$ of global carbon) is stored in marine blue carbon repositories (Duarte et al. 2013).

The mechanisms of damage include changing species distributions (so carbon is no longer stored efficiently), dissolution of habitats that store carbon by ocean acidification (Brodie et al. 2014, van der Heijden and Kamenos 2015a), extreme climatic events (Arias-Ortiz et al. 2018) or mechanical destruction of such communities (Serrano et al. 2016). The consequences of damage to blue carbon ecosystems is a reduction in removal of atmospheric $\mathrm{CO}_{2}$ further exacerbating global warming and ocean acidification (Duarte et al. 2013). In addition, the removal of these ecosystems leads to a significant loss in coastal protection and thus a loss in land and further carbon (e.g. via loss of coastal salt marshes; (Fitton et al. 2016). Globally, the loss of blue carbon ecosystems due to climate change represents a storage capacity loss of 7-29 $\mathrm{Tg} \mathrm{CO}_{2}$ per year (Duarte et al. 2013) resulting in an estimated $£ 5-34$ billion per year loss of $\mathrm{CO}_{2}$ sequestration alone (Pendleton et al. 2012). In the UK, coastal habitats alone (e.g. saltmarshes) are estimated to contribute $£ 1 \mathrm{bn}$ in $\mathrm{CO}_{2}$ sequestration, however, that may fall to $€ 0.25 \mathrm{bn}$ by 2060 if habitat loss continues (Beaumont et al. 2014).

- Climate regulation: In addition to the role of carbon storage in climate regulation, marine biodiversity is, in part, controlled through biogeochemical cycling by marine biota. For example, emission of sulphurbased gases in the coastal zone (Burdett et al. 2015) may contribute to climate regulation (for example stablizing climate; Charlson et al. 1987). As with carbon storage, loss of such services will impact the rate of climate change.

- Coastal protection: Within the UK, coastal habitats account for $\sim £ 50$ billion of services including coastal protection from marine ingress, for example, by protecting coastal communities during storm surges (Fitton et al. 2016). Saltmarshes alone are predicted to reduce in extent by $25 \%$ by 2100 exposing coastal communities to flooding losing up to $25 \%$ of the $£ 1 \mathrm{bn}$ services, including carbon storage, they provide (Beaumont et al. 2014) .

- Aquaculture and fisheries: UK aquaculture is worth $£ 800$ million across all species (www.seafish.com), while fisheries landings into the UK by the home fleet in 2015 were valued at $€ 775$ million (Marine Management Organisation 2015). The stressors described above are likely to change the species targeted by both in UK waters, potentially causing a loss of employment (Beaumont et al. 2006) and possibly affecting food supply chains. Projected levels of ocean warming would lead to relocation of cod (Drinkwater 2005) while projected ocean acidification would cause increased fragility in mussel shells (Fitzer et al. 2014), making them unsuitable for aquaculture. Not all species are likely to be impacted by warming and ocean acidification.

- Raw materials: Biodiversity is responsible for the provision of materials including seaweeds which are commonly used as soil conditioners (Brodie et al. 2014) as well as fish meal which is used as an aquaculture food source (Beaumont et al. 2008) and marine genetic resources which come from the raw materials collected (Leary et al. 2009). Changes to the type of seaweed available (see above) could affect not only 
direct unemployment of the harvesters, but indirectly the aquaculture industry (De Silva and Soto 2009).

- As marine genetic resources often come from raw materials, the stressors affecting biodiversity, for example, are also likely to affect marine genetic resources such as those used for medicinal applications (Beaumont et al. 2006).

- Bioremediation: Marine biota can modify anthropogenic waste via burial, dilution and detoxification, effectively removing these wastes from the environment (e.g. significant breakdown of oil spills by marine bacteria; Gutierrez et al. 2013). The impact of climate change on this process is uncertain as valuations for the UK do not exist.

- Recreation: Biodiversity supports human use of the marine environment (e.g. fishing and SCUBA diving). MPAs alone are estimated to provide $£ 3.9$ billion in services (Kenter et al. 2013). The monetary value of the loss of these services extended to the whole UK coastlines is expected to be significantly higher as MPAs only cover 4\% of the UK's seas and valuations have not been made of Overseas Territories, where extensive MPAs exist (e.g. St. Helena).

- Should marine biodiversity decline, this would result in reduced technological and medicinal applications with subsequent economic implications (Beaumont et al. 2006).

- Ability of marine environments to recover (resilience): As biodiversity declines due to ocean warming, marine systems lose their ability to recover from other disturbances (e.g. pollution). This is particularly hard to value, as it interacts with many of the above impacts with complex outcomes. For example, in Australia, warming reduced the ability of habitat forming seaweeds to recover from the stressor as juveniles could not compete ecologically (Wernberg et al. 2010). Overall, reduced resilience due to reduced climate change will exacerbate the other impacts of reduced biodiversity as systems will be very slow to recover.

\section{Legislation}

Climate change and biodiversity loss pose new challenges for legislation, in particular for legislation intended to promote sustainable marine resource management (Frost et al. 2016). The implications of climate change for the designation and management of MPAs are major (see above). This is a significant field for policymakers, but it is beyond the scope of the present review. For further, detailed reading, the reader is referred to a recent review paper (Frost et al. 2016).

The significance of natural carbon removal from the global system to help control climate change is such that international legislation now exists to respond to this. At present legal mechanisms exist for encouraging the mitigation of climate change through natural vegetated systems. These mechanisms are focused mainly on terrestrial vegetation; for example the United Nations Framework Convention on Climate Change (UNFCCC); Reducing Emissions through Decreased Deforestation (REDD+) and National Appropriate Mitigation Actions (NAMAs). Indeed, the UNFCCC has the Clean Development Mechanism which allows emission-reduction projects in developing countries to generate certified emission reduction credits. For the UK, coastal eco-engineering approaches that provide impetus for increased growth of UK blue carbon repositories may be an approach to ensure continued carbon sequestration (e.g. the provision of marine protection to enhance growth of carbon sequestering ecosystems). One of the challenges for effective conservation legislation in the UK is the occurrence of large-scale cold-water coral reefs in international waters close to, but outside, the UK's national jurisdiction (Roberts and Cairns 2014). This reflects the importance of international agreements relating to biodiversity protection.

At present the UK is subject to international and European law and has signed agreements relating to marine biodiversity. At the international level, this includes the Convention on Biological Diversity (CBD, https://www. cbd.int/) and the UN Sustainable Development Goal 14 (Life Below the Sea) to ensure the conservation and sustainable use of the oceans and marine resources by reducing pollution and strengthening their resilience against a background of climate change by management, enhanced scientific collaboration and sustainable resource use.

Acknowledgments: Funding from the UK Natural Environment Research Council (NERC) through Oceans 2025 (WP4.5), Funder Id: 10.13039/501100000270, Grant Number: Oceans 2025 - WP 4.5 and the MASTS pooling initiative (Marine Alliance for Science and Technology for Scotland, funded by the Scottish Funding Council and contributing institutions; grant reference HR09011) is gratefully acknowledged.

\section{References}

Alemu I, J.B. and Y. Clement. 2014. Mass coral bleaching in 2010 in the Southern Caribbean. PLoS One 9: e83829. 
Alley, R.B. and I. Joughin. 2012. Modeling ice-sheet flow. Science 336: 551-552.

Allison, E.H., A.L. Perry, M.C. Badjeck, W.N. Adger, K. Brown, D. Conway, A.S. Halls, G.M. Pilling, J.D. Reynolds, N.L. Andrew and N.K. Dulvy. 2009. Vulnerability of national economies to the impacts of climate change on fisheries. Fish. Fish. 10: 173-196.

Andrady, A.L. 2011. Microplastics in the marine environment. Mar. Pollut. Bull. 62: 1596-1605.

Arias-Ortiz, A., O. Serrano, P. Masque, P.S. Lavery, U. Mueller, G.A. Kendrick, M. Rozaimi, A. Esteban, J.W. Fourqurean, N. Marbà, M.A. Mateo, K. Murray, M.J. Rule and C.M. Duarte. 2018. A marine heatwave drives massive losses from the world's largest seagrass carbon stocks. Nat. Clim. Chang. 8: 338-344.

Asensi, A.O. and F.C. Küpper. 2012. Seasonal periodicity and reproduction of brown algae (Phaeophyta) at Puerto Deseado (Patagonia). Bot. Mar. 55: 217-228.

Bacon, P.R. and G.P. Alleng. 1992. The management of insular caribbean mangroves in relation to site location and community type. Hydrobiologia 247: 235-241.

Baptista, M.S., R.J. Miller, E.R. Halewood, S.K. Hanna, C.M.R. Almeida, V.M. Vasconcelos, A.A. Keller and H.S. Lenihan. 2015. Impacts of silver nanoparticles on a natural estuarine plankton community. Environ. Sci. Technol. 49: 12968-12974.

Barnes, D.K.A. 2002. Biodiversity - invasions by marine life on plastic debris. Nature 416: 808-809.

Bartsch, I., C. Wiencke, K. Bischof, C.M. Buchholz, B.H. Buck, A. Eggert, P. Feuerpfeil, D. Hanelt, S. Jacobsen, R. Karez, U. Karsten, M. Molis, M. Roleda, R. Schumann, H. Schubert, K. U. Valentin, F. Weinberger and J. Wiese. 2008. The genus Laminaria sensu lato: recent insights and developments. Eur. J. Phycol. 43: 1-86.

Baum, J.K., R.A. Myers, D.G. Kehler, B. Worm, S.J. Harley and P.A. Doherty. 2003. Collapse and conservation of shark populations in the Northwest Atlantic. Science 299: 389-392.

Baylis, A.M.M., A.F. Zuur, P. Brickle and P.A. Pistorius. 2012. Climate as a driver of population variability in breeding Gentoo Penguins Pygoscelis papua at the Falkland Islands. Ibis 154: 30-41.

Beare, D.J., F. Burns, A. Greig, E.G. Jones, K. Peach, M. Kienzle, E. McKenzie and D.G. Reid. 2004. Long-term increases in prevalence of North Sea fishes having southern biogeographic affinities. Mar. Ecol. Prog. Ser. 284: 269-278.

Beaumont, N., M. Townsend, S. Mangi and M. Austen. 2006. Marine Biodiversity. An economic valuation. Building the evidence base for the Marine Bill. Defra London July 2006. 1-64.

Beaumont, N., M. Austen, S. Mangi and M. Townsend. 2008. Economic valuation for the conservation of marine biodiversity. Mar. Pollut. Bull. 56: 386-396.

Beaumont, N.J., L. Jones, A. Garbutt, J.D. Hansom and M. Toberman. 2014. The value of carbon sequestration and storage in coastal habitats. Estuar. Coast. Shelf Sci. 137: 32-40.

Bellard, C., C. Bertelsmeier, P. Leadley, W. Thuiller and F. Courchamp. 2012. Impacts of climate change on the future of biodiversity. Ecol. Lett. 15: 365-377.

Bielmyer-Fraser, G.K., T.A. Jarvis, H.S. Lenihan and R.J. Miller. 2014. Cellular partitioning of nanoparticulate versus dissolved metals in marine phytoplankton. Environ. Sci. Technol. 48: 13443-13450.
Blanchard, J.L., C. Mills, S. Jennings, C.J. Fox, B.D. Rackham, P.D. Eastwood and C.M. O'Brien. 2005. Distribution-abundance relationships for North Sea Atlantic cod (Gadus morhua): observation versus theory. Can. J. Fish. Aquat. Sci. 62: 2001-2009.

Brickle, P., J. Brown, F.C. Küpper and P.E. Brewin. 2017. Biodiversity of the marine environment around Ascension Island, South Atlantic. J. Mar. Biol. Assoc. U.K. 97: 643-646.

Brodie, J., C.J. Williamson, D.A. Smale, N.A. Kamenos, N. Mieszkowska, R. Santos, M. Cunliffe, M. Steinke, C. Yesson, K.M. Anderson, V. Asnaghi, C. Brownlee, H.L. Burdett, M.T. Burrows, S. Collins, P.J.C. Donohue, B. Harvey, A. Foggo, F. Noisette, J. Nunes, F. Ragazzolam J.A. Raven, D.N. Schmidt, D. Suggett, M. Teichberg and J.M. Hall-Spencer. 2014. The future of the northeast Atlantic benthic flora in a high $\mathrm{CO} 2$ world. Ecol. Evol. 4: $2787-2798$.

Burchardt, A.D., R.N. Carvalho, A. Valente, P. Nativo, D. Gilliland, C.P. Garcia, R. Passarella, V. Pedroni, F. Rossi and T. Lettieri. 2012. Effects of Silver Nanoparticles in Diatom Thalassiosira pseudonana and Cyanobacterium Synechococcus sp. Environ. Sci. Technol. 46: 11336-11344.

Burdett, H.L., A.D. Hatton and N.A. Kamenos. 2015. Coralline algae are a globally significant pool of marine dimethylated sulphur. Global Biogeochem. Cycles 29: 1845-1853.

Carleton, C. and K. Lawrence. 2005. Economic valuation of environmental resource services in the Turks and Caicos Islands. Prepared for the Government of the Turks and Caicos Islands by Nautilus Consultants Ltd., Peebles, UK.

Charlson, R.J., J.E. Lovelock, M.O. Andreae and S.G. Warren. 1987. Oceanic phytoplankton, atmospheric sulphur, cloud albedo and climate. Nature 326: 655-661.

Cheung, W.W., V.W. Lam, J.L. Sarmiento, K. Kearney, R. Watson and D. Pauly. 2009a. Projecting global marine biodiversity impacts under climate change scenarios. Fish. Fish. 10: 235-251.

Cheung, W.W.L., V.W.Y. Lam, J.L. Sarmiento, K. Kearney, R. Watson and D. Pauly. 2009b. Projecting global marine biodiversity impacts under climate change scenarios. Fish. Fish. 10: 235-251.

Cipollini, P., F.M. Calafat, S. Jevrejeva, A. Melet and P. Prandi. 2017. Monitoring sea level in the coastal zone with satellite altimetry and tide gauges. Surv. Geophys. 38: 33-57.

Clark, R.A., C.J. Fox, D. Viner and M. Livermore. 2003. North Sea cod and climate change - modelling the effects of temperature on population dynamics. Glob. Change Biol. 9: 1669-1680.

Collins, M.A., P. Brickle, J. Brown and M. Belchier. 2010. The Patagonian toothfish: biology, ecology and fishery. In: (M. Lesser, ed) Advances in Marine Biology, Vol 58. Elsevier Academic Press Inc, San Diego. pp. 227-300.

Das, P., C.D. Metcalfe and M.A. Xenopoulos. 2014. Interactive effects of silver nanoparticles and phosphorus on phytoplankton growth in natural waters. Environ. Sci. Technol. 48: 4573-4580.

De Silva, S.S. and D. Soto. 2009. Climate change and aquaculture: potential impacts, adaptation and mitigation. Climate change implications for fisheries and aquaculture: overview of current scientific knowledge. FAO Fisheries and Aquaculture Technical Paper 151-212.

Doiron, K., E. Pelletier and K. Lemarchand. 2012. Impact of polymercoated silver nanoparticles on marine microbial communities: a microcosm study. Aquat. Toxicol. 124: 22-27.

Drinkwater, K.F. 2005. The response of Atlantic cod (Gadus morhua) to future climate change. ICES J. Mar. Sci. 62: 1327-1337. 
Duarte, C.M., I.J. Losada, I.E. Hendriks, I. Mazarrasa and N. Marba. 2013. The role of coastal plant communities for climate change mitigation and adaptation. Nature Clim. Change 3: 961-968.

Eakin, C.M., J.A. Morgan, S.F. Heron, T.B. Smith, G. Liu, L. AlvarezFilip, B. Baca, E. Bartels, C. Bastidas, C. Bouchon, M. Brandt, A.W. Bruckner, L. Bunkley-Williams, A. Cameron, B.D. Causey, M. Chiappone, T.R. Christensen, M.J. Crabbe, O. Day, E. de la Guardia, G. Díaz-Pulido, D. DiResta, D.L. Gil-Agudelo, D.S Gilliam, R.N. Ginsburg, S. Gore, H.M. Guzmán, J.C. Hendee, E.A. Hernández-Delgado, E. Husain, C.F. Jeffrey, R.J. Jones, E. Jordán-Dahlgren, L.S. Kaufman, D.I. Kline, P.A. Kramer, J.C. Lang, D. Lirman, J. Mallela, C. Manfrino, J.P. Maréchal, K. Marks, J. Mihaly, W.J. Miller, E.M. Mueller, E.M. Muller, C.A. Orozco Toro, H.A. Oxenford, D. Ponce-Taylor, N. Quinn, K.B. Ritchie, S. Rodríguez, A.R. Ramírez, S. Romano, J.F. Samhouri, J.A. Sánchez, G.P. Schmahl, B.V. Shank, W.J. Skirving, S.C. Steiner, E. Villamizar, S.M. Walsh, C. Walter, E. Weil, E.H. Williams, K.W. Roberson and Y. Yusuf. 2010. Caribbean corals in crisis: record thermal stress, bleaching, and mortality in 2005. PLoS One 5: e13969.

Eggert, A., A.F. Peters and F.C. Küpper. 2010. The potential impact of climate change on endophyte infections in kelp sporophytes. In: (A. Israel, R. Einav and J. Seckbach, eds) Seaweeds and Their Role in Globally Changing Environments. Springer, Dordrecht. pp. 139-154.

Ellison, J.C. 1993. Mangrove retreat with rising sea-level, Bermuda. Estuar. Coast. Shelf Sci. 37: 75-87.

Engelhard, G.H., D.A. Righton and J.K. Pinnegar. 2014. Climate change and fishing: a century of shifting distribution in North Sea cod. Glob. Change Biol. 20: 2473-2483.

Ermgassen, P., J.H. Grabowski, J.R. Gair and S.P. Powers. 2016. Quantifying fish and mobile invertebrate production from a threatened nursery habitat. J. Appl. Ecol. 53: 596-606.

Fitton, J.M., J.D. Hansom and A.F. Rennie. 2016. A national coastal erosion susceptibility model for Scotland. Ocean Coast Manag. 132: 80-89.

Fitzer, S.C., V.R. Phoenix, M. Cusack and N.A. Kamenos. 2014. Ocean acidification changes mussel control on biomineralisation. Sci. Rep. 4: 6218.

Frederiksen, M., T. Anker-Nilssen, G. Beaugrand and S. Wanless. 2013. Climate, copepods and seabirds in the boreal Northeast Atlantic - current state and future outlook. Glob. Change Biol. 19: 364-372.

Frid, C.L.J. and B.A. Caswell. 2015. Is long-term ecological functioning stable: the case of the marine benthos? J. Sea Res. 98: 15-23.

Frost, M., G. Bayliss-Brown, P. Buckley, M. Cox, S.R. Dye, W.G. Sanderson, B. Stoker and N. Withers Harvey. 2016. A review of climate change and the implementation of marine biodiversity legislation in the United Kingdom. Aquat. Conserv. 26: 576-595.

Gallagher, A., A. Rees, R. Rowe, J. Stevens and P. Wright. 2016. Microplastics in the Solent estuarine complex, UK: an initial assessment. Mar. Pollut. Bull. 102: 243-249.

Genner, M.J., J.J. Freer and L.A. Rutterford. Biological responses to oean warming. In Foresight - Future of the Sea Evidence Review. London, UK, 2017.

Gormley, K.S.G., J.S. Porter, M.C. Bell, A.D. Hull and W.G. Sanderson. 2013. Predictive habitat modelling as a tool to assess the change in distribution and extent of an OSPAR priority habitat under an increased ocean temperature scenario: consequences for marine protected area networks and management. PLoS One 8: e68263.

Green, E.P., C.D. Clark, P.J. Mumby, A.J. Edwards and A.C. Ellis. 1998a. Remote sensing techniques for mangrove mapping. Int. J. Remote Sens. 19: 935-956.

Green, E.P., P.J. Mumby, A.J. Edwards, C.D. Clark and A.C. Ellis. $1998 \mathrm{~b}$. The assessment of mangrove areas using high resolution multispectral airborne imagery. J. Coast. Res. 14: 433-443.

Gregory, M.R. 2009. Environmental implications of plastic debris in marine settings-entanglement, ingestion, smothering, hangers-on, hitch-hiking and alien invasions. Philos. Trans. $R$. Soc. B-Biol. Sci. 364: 2013-2025.

Gutierrez, T., D.R. Singleton, D. Berry, T. Yang, M.D. Aitken and A. Teske. 2013. Hydrocarbon-degrading bacteria enriched by the Deepwater Horizon oil spill identified by cultivation and DNASIP. ISME J. 7: 2091-2104.

Hennige, S.J., L.C. Wicks, N.A. Kamenos, G. Perna, H.S. Findlay and J.M. Roberts. 2015. Hidden impacts of ocean acidification to live and dead coral framework. Proc. R. Soc. B. 282: 20150990

Henry, L.G., J.F. McManus, W.B. Curry, N.L. Roberts, A.M. Piotrowski and L.D. Keigwin. 2016. North Atlantic ocean circulation and abrupt climate change during the last glaciation. Science 353: 470-474.

Hiddink, J.G. and R. ter Hofstede. 2008. Climate induced increases in species richness of marine fishes. Glob. Change Biol. 14: 453-460.

Hilton, G.M. and R.J. Cuthbert. 2010. The catastrophic impact of invasive mammalian predators on birds of the UK Overseas Territories: a review and synthesis. Ibis 152: 443-458.

Hixon, M.A., S.J. Green, M.A. Albins, J.L. Akins and J.A. Morris. 2016. Lionfish: a major marine invasion. Marine Ecology Progress Series 558: 161-165.

Hogg, O.T., D.K.A. Barnes and H.J. Griffiths. 2011. Highly diverse, poorly studied and uniquely threatened by climate change: an assessment of marine biodiversity on South Georgia's continental shelf. PLoS One 6: e19795.

Horton, A.A., C. Svendsen, R.J. Williams, D.J. Spurgeon and E. Lahive. 2017. Large microplastic particles in sediments of tributaries of the River Thames, UK - Abundance, sources and methods for effective quantification. Mar. Pollut. Bull. 114: 218-226.

Huijbers, C.M., M.G.G. Grol and I. Nagelkerken. 2008. Shallow patch reefs as alternative habitats for early juveniles of some mangrove/seagrass-associated fish species in Bermuda. Rev. Biol. Trop. 56: 161-169.

Jackson, J.B.C. 2008. Ecological extinction and evolution in the brave new ocean. Proc. Natl. Acad. Sci. U.S.A. 105: 11458-11465.

Jackson, J.B.C., M.X. Kirby, W.H. Berger, K.A. Bjorndal, L.W. Botsford, B.J. Bourque, R.H. Bradbury, R. Cooke, J. Erlandson, J.A. Estes, T.P. Hughes, S. Kidwell, C.B. Lange, H.S. Lenihan, J.M. Pandolfi, C.H. Peterson, R.S. Steneck, M.J. Tegner and R.R. Warner. 2001. Historical overfishing and the recent collapse of coastal ecosystems. Science 293: 629-638.

Kenter, J.O., R. Bryce, A. Davies, N. Jobstvogt, V. Watson, S. Ranger, J.-L. Solandt, C. Duncan, M. Christie, H. Crump, K.N. Irvine, M. Pinard and M.S. Reed. 2013. The value of potential marine protected areas in the UK to divers and sea anglers. UNEP-WCMC, Cambridge, UK.

King, N.G., N.J. McKeown, D.A. Smale and P.J. Moore. 2018a. The importance of phenotypic plasticity and local adaptation in 
driving intraspecific variability in thermal niches of marine macrophytes. Ecography 41: 1469-1484.

King, N.G., D.C. Wilcockson, R. Webster, D.A. Smale, L.S. Hoelters and P.J. Moore. 2018b. Cumulative stress restricts niche filling potential of habitat-forming kelps in a future climate. Funct. Ecol. 32: 288-299.

Knowlton, N. and J.B.C. Jackson. 2008. Shifting baselines, local impacts, and global change on coral reefs. PLoS. Biol. 6: 215-220.

Krause-Jensen, D. and C.M. Duarte. 2016. Substantial role of macroalgae in marine carbon sequestration. Nat. Geosci. 9: 737-742.

Krause-Jensen, D., P. Lavery, O. Serrano, N. Marba, P. Masque and C.M. Duarte. 2018. Sequestration of macroalgal carbon: the elephant in the Blue Carbon room. Biol. Lett. 14: 20180236.

Kroeker, K.J., R.L. Kordas, R. Crim, I.E. Hendriks, L. Ramajo, G.S. Singh, C.M. Duarte and J.-P. Gattuso. 2013. Impacts of ocean acidification on marine organisms: quantifying sensitivities and interaction with warming. Glob. Change Biol. 19: 1884-1896.

Küpper, F.C., M.C. Feiters, B. Olofsson, T. Kaiho, S. Yanagida, M.B. Zimmermann, L.J. Carpenter, G.W. Luther 3rd, Z. Lu, M. Jonsson and L. Kloo. 2011. Commemorating two centuries of iodine research: an interdisciplinary overview of current research. Angew Chem. Int. Ed. Engl. 50: 11598-11620.

Küpper, F.C., A.F. Peters, D.M. Shewring, M.D.J. Sayer, A. Mystikou, H. Brown, E. Azzopardi, O. Dargent, M. Strittmatter, D. Brennan, A.O. Asensi, P. van West and R.T. Wilce. 2016. Arctic marine phytobenthos of northern Baffin Island. J. Phycol. 52: 532-549.

Leary, D., M. Vierros, G. Hamon, S. Arico and C. Monagle. 2009. Marine genetic resources: a review of scientific and commercial interest. Mar. Policy 33: 183-194.

Mackenzie, B.R. and D. Schiedek. 2007. Daily ocean monitoring since the 1860s shows record warming of northern European seas. Glob. Change Biol. 13: 1335-1347.

Marba, N., A. Arias-Ortiz, P. Masque, G.A. Kendrick, I. Mazarrasa, G.R. Bastyan, J. Garcia-Orellana and C.M. Duarte. 2015. Impact of seagrass loss and subsequent revegetation on carbon sequestration and stocks. J. Ecol. 103: 296-302.

Mason, S.A., D. Garneau, R. Sutton, Y. Chu, K. Ehmann, J. Barnes, P. Fink, D. Papazissimos and D.L. Rogers. 2016. Microplastic pollution is widely detected in US municipal wastewater treatment plant effluent. Environ. Pollut. 218: 1045-1054.

Mazarrasa, I., N. Marba, J. Garcia-Orellana, P. Masque, A. Arias-Ortiz and C.M. Duarte. 2017a. Dynamics of carbon sources supporting burial in seagrass sediments under increasing anthropogenic pressure. Limnol. Oceanogr. 62: 1451-1465.

Mazarrasa, I., N. Marba, J. Garcia-Orellana, P. Masque, A. Arias-Ortiz and C.M. Duarte. 2017b. Effect of environmental factors (wave exposure and depth) and anthropogenic pressure in the $\mathrm{C}$ sink capacity of Posidonia oceanica meadows. Limnol. Oceanogr. 62: 1436-1450.

McCarthy, G.D., I.D. Haigh, J.J.M. Hirschi, J.P. Grist and D.A. Smeed. 2015. Ocean impact on decadal Atlantic climate variability revealed by sea-level observations. Nature 521: 508-510.

MCCIP. 2015. Marine climate change impacts: implications for the implementation of marine biodiversity legislation. Lowestoft.

Minchin, D., E.J. Cook and P.F. Clark. 2013. Alien species in British brackish and marine waters. Aquat. Invasions 8: 3-19.
Mystikou, A., A. Peters, A. Asensi, K. Fletcher, P. Brickle, P. van West, P. Convey and F.C. Küpper. 2014. Seaweed biodiversity in the south-western Antarctic Peninsula: surveying macroalgal community composition in the Adelaide Island/Marguerite Bay region over a 35-year time span. Polar Biol. 37: 1607-1619.

Mystikou, A., A.O. Asensi, O. De Clerck, D.G. Müller, A.F. Peters, K. Tsiamis, D.M. Shewring, K.I. Fletcher, R. Westermeier, P. Brickle, P. Van West and F.C. Küpper. 2016. New records and reassessment of macroalgae and associated pathogens from the Falkland Islands, Patagonia and Tierra del Fuego. Bot. Mar. 59: 105-121.

National Archives. 2013. The exclusive economic zone order 2013. In Kew, Richmond, Surrey.

Oliver, E.C.J., M.G. Donat, M.T. Burrows, P.J. Moore, D.A. Smale, L.V. Alexander, J.A. Benthuysen, M. Feng, A. Sen Gupta, A.J. Hobday, N.J. Holbrook, S.E. Perkins-Kirkpatrick, H.A. Scannell, S.C. Straub and T. Wernberg. 2018. Longer and more frequent marine heatwaves over the past century. Nat. Commun. 9: 1324.

Outerbridge, M.E., R. O'Riordan, T. Quirke and J. Davenport. 2017. Restricted diet in a vulnerable native turtle, Malaclemys terrapin (Schoepff), on the oceanic islands of Bermuda. Amphib. Reptile Conserv. 11: 25-35.

Paddack, M.J., J.D. Reynolds, C. Aguilar, R.S. Appeldoorn, J. Beets, E.W. Burkett, P.M. Chittaro, K. Clarke, R. Esteves, A.C. Fonseca, G.E. Forrester, A.M. Friedlander, J. García-Sais, G. GonzálezSansón, L.K. Jordan, D.B. McClellan, M.W. Miller, P.P. Molloy, P.J. Mumby, I. Nagelkerken, M. Nemeth, R. Navas-Camacho, J. Pitt, N.V. Polunin, M.C. Reyes-Nivia, D.R. Robertson, A. Rodríguez-Ramírez, E. Salas, S.R. Smith, R.E. Spieler, M.A. Steele, I.D. Williams, C.L. Wormald, A.R. Watkinson and I.M. Cote. 2009. Recent region-wide declines in caribbean reef fish abundance. Curr. Biol. 19: 590-595.

Peck, L.S., K.E. Webb and D.M. Bailey. 2004. Extreme sensitivity of biological function to temperature in Antarctic marine species. Funct. Ecol. 18: 625-630.

Pellerin, A., T.H. Bui, M. Rough, A. Mucci, D.E. Canfield and B.A. Wing. 2015. Mass-dependent sulfur isotope fractionation during reoxidative sulfur cycling: a case study from Mangrove Lake, Bermuda. Geochim. Cosmochim. Acta 149: 152-164.

Pendleton, L., D.C. Donato, B.C. Murray, S. Crooks, W.A. Jenkins, S. Sifleet, C. Craft, J.W. Fourqurean, J.B. Kauffman, N. Marbà, P. Megonigal, E. Pidgeon, D. Herr, D. Gordon and A. Baldera. 2012. Estimating global "blue carbon" emissions from conversion and degradation of vegetated coastal ecosystems. PLoS One 7: e43542.

Perry, A.L., P.J. Low, J.R. Ellis and J.D. Reynolds. 2005. Climate change and distribution shifts in marine fishes. Science 308: 1912-1915.

Pfingstl, T., A. Lienhard and J. Jagersbacher-Baumann. 2014. Hidden in the mangrove forest: the cryptic intertidal mite Carinozetes mangrovi sp nov (Acari, Oribatida, Selenoribatidae). Exp. Appl. Acarol. 63: 481-495.

Price, J.H. and D.M. John. 1978. Subtidal ecology in Antigua and Ascension: a comparison. Progress in Underwater Science 3: 111-133.

Price, J.H. and D.M. John. 1980. Ascension Island, South Atlantic - A survey of inshore benthic macroorganisms, communities and interactions. Aquat. Bot. 9: 251-278. 
Ramírez, F., I. Afán, L.S. Davis and A. Chiaradia. 2017. Climate impacts on global hot spots of marine biodiversity. Sci. Adv. 3: e1601198.

Reef, R., T. Spencer, I. Moller, C.E. Lovelock, E.K. Christie, A.L. Mclvor, B.R. Evans and J.A. Tempest. 2017. The effects of elevated $\mathrm{CO} 2$ and eutrophication on surface elevation gain in a European salt marsh. Glob. Change Biol. 23: 881-890.

Roberts, J.M. and S.D. Cairns. 2014. Cold-water corals in a changing ocean. Curr. Opin. Environ. Sustain. 7: 118-126.

Roberts, J.M., A.J. Wheeler and A. Freiwald. 2006. Reefs of the deep: the biology and geology of cold-water coral ecosystems. Science 312: 543-547.

Rocha, L.A., C.R. Rocha, C.C. Baldwin, L.A. Weigt and M. McField. 2015. Invasive lionfish preying on critically endangered reef fish. Coral Reefs 34: 803-806.

Roy, H.E., J. Peyton, D.C. Aldridge, T. Bantock, T.M. Blackburn, R. Britton, P. Clark, E. Cook, K. Dehnen-Schmutz, T. Dines, M. Dobson, F. Edwards, C. Harrower, M.C. Harvey, D. Minchin, D.G. Noble, D. Parrott, M.J. Pocock, C.D. Preston, S. Roy, A. Salisbury, K. Schönrogge, J. Sewell, R.H. Shaw, P. Stebbing, A.J. Stewart and K.J. Walker. 2014. Horizon scanning for invasive alien species with the potential to threaten biodiversity in Great Britain. Glob. Change Biol. 20: 3859-3871.

Sabatino, A.D., R.B. Murray, A. Hills, D.C. Speirs and M.R. Heath. 2016. Modelling sea level surges in the Firth of Clyde, a fjordic embayment in south-west Scotland. Nat. Hazards 84: 1601-1623.

Sarkis, S., P.J.H. van Beukering, E. McKenzie, S. Hess, L. Brander, M. Roelfsema, L. Looijenstijn-van der Putten and T. Bervoets. 2010. Total economic value of Bermuda's coral reefs: valuation of ecosystem services, Technical Report. In Bermuda. p. 199.

Schneider, C.W. and C.E. Lane. 2007. Notes on the marine algae of the Bermudas. 8. Further additions to the flora, including Griffithsia aestivana sp nov (Ceramiaceae, Rhodophyta) and an update on the alien Cystoseira compressa (Sargassaceae, Heterokontophyta). Bot. Mar. 50: 128-140.

Serpetti, N., A.R. Baudron, M.T. Burrows, B.L. Payne, P. Helaouet, P.G. Fernandes and J.J. Heymans. 2017. Impact of ocean warming on sustainable fisheries management informs the Ecosystem Approach to Fisheries. Sci. Rep. 7: 13438.

Serrano, O., R. Ruhon, P.S. Lavery, G.A. Kendrick, S. Hickey, P. Masque, A. Arias-Ortiz, A. Steven and C.M. Duarte. 2016. Impact of mooring activities on carbon stocks in seagrass meadows. Sci. Rep. 6: 23193.

Sheppard, C.R.C., M. Ateweberhan, B.W. Bowen, P. Carr, C.A. Chen, C. Clubbe, M. T. Craig, R. Ebinghaus, J. Eble, N. Fitzsimmons, M. R. Gaither, C.-H. Gan, M. Gollock, N. Guzman, N. A. J. Graham, A. Harris, R. Jones, S. Keshavmurthy, H. Koldewey, C. G. Lundin, J. A. Mortimer, D. Obura, M. Pfeiffer, A. R. G. Price, S. Purkis, P. Raines, J. W. Readman, B. Riegl, A. Rogers, M. Schleyer, M. R. D Seaward, A. L. S. Sheppard, J. Tamelander, J. R. Turner, S. Visram, C. Vogler, S. Vogt, H. Wolschke, J. M.-C. Yang, S.-Y. Yang and C. Yesson. 2012. Reefs and islands of the Chagos Archipelago, Indian Ocean: why it is the world's largest no-take marine protected area. Aquat. Conserv.-Mar. Freshw. Ecosyst. 22: 232-261.

Smale, D.A. and T. Vance. 2016. Climate-driven shifts in species' distributions may exacerbate the impacts of storm disturbances on North-east Atlantic kelp forests. Mar. Freshw. Res. 67: 65-74.
Smale, D.A., T. Wernberg, A.L.E. Yunnie and T. Vance. 2015. The rise of Laminaria ochroleuca in the Western English Channel (UK) and comparisons with its competitor and assemblage dominant Laminaria hyperborea. Mar. Ecol.-Evol. Persp. 36: 1033-1044.

Smale, D.A., M.T. Burrows, A.J. Evans, N. King, M.D.J. Sayer, A.L.E. Yunnie and P.J. Moore. 2016. Linking environmental variables with regional-scale variability in ecological structure and standing stock of carbon within UK kelp forests. Mar. Ecol. Prog. Ser. 542: 79-95.

Smith, A.D.M., C.J. Brown, C.M. Bulman, E.A. Fulton, P. Johnson, I.C. Kaplan, H. Lozano-Montes, S. Mackinson, M. Marzloff, L.J. Shannon, Y.J. Shin and J. Tam. 2011. Impacts of fishing low-trophic level species on marine ecosystems. Science 333: 1147-1150.

Syamjith, P.K. and N. Ramani. 2013. Association of a mangrove dwelling euphthiracarid mite, Acrotritia clavata (Markel 1964) (Acari: Oribatida) with the epiphytic alga, Microspora sp. Int. J. Acarol. 39: 615-619.

Teagle, H. and D.A. Smale. 2018. Climate-driven substitution of habitat-forming species leads to reduced biodiversity within a temperate marine community. Diversity and Distributions 24: 1367-1380.

Thomas, C.D., A. Cameron, R.E. Green, M. Bakkenes, L.J. Beaumont, Y.C. Collingham, B.F.N. Erasmus, M. Ferreira de Siqueira, A. Grainger, L. Hannah, L. Hughes, B. Huntley, A.S. van Jaarsveld, G.F. Midgley, L. Miles, M.A. Ortega-Huerta, A.T. Peterson, O.L. Phillips and Stephen E. Williams. 2004. Extinction risk from climate change. Nature 427: 145-148.

Trevathan-Tackett, S.M., J. Kelleway, P.I. Macreadie, J. Beardall, P. Ralph and A. Bellgrove. 2015. Comparison of marine macrophytes for their contributions to blue carbon sequestration. Ecology 96: 3043-3057.

Tsiamis, K., P. Panayotidis, M. Salomidi, A. Pavlidou, J. Kleinteich, K. Balanika and F.C. Küpper. 2013. Macroalgal community response to re-oligotrophication: Saronikos Gulf. Mar. Ecol.-Prog. Ser. 472: 73-85.

Tsiamis, K., A.F. Peters, D.M. Shewring, A.O. Asensi, P. Van West and F.C. Küpper. 2017. Marine benthic algal flora of Ascension Island, South Atlantic. J. Mar. Biol. Assoc. U.K. 97: 681-688.

Tsiola, A., C. Toncelli, S. Fodelianakis, G. Michoud, T.D. Bucheli, A. Gavriilidou, M. Kagiorgi, I. Kalantzi, K. Knauer, G. Kotoulas, K. Mylona, E. Papadopoulou, S. Psarra, I. Santi, M. Tsapakis, D. Daffonchio, S.A. Pergantis and P. Pitta. 2018. Low-dose addition of silver nanoparticles stresses marine plankton communities. Environ.-Sci. Nano 5: 1965-1980.

van der Heijden, L. and N.A. Kamenos. 2015a. Calculating the global contribution of coralline algae to total carbon burial. Biogeosciences (BG) 12: 6429-6441.

van der Heijden, L.H. and N.A. Kamenos. 2015b. Reviews and syntheses: calculating the global contribution of coralline algae to total carbon burial. Biogeosciences 12: 6429-6441.

Waycott, M., G. Procaccini, D.H. Les and T.B.H. Reusch. 2006. Seagrass evolution, ecology and conservation: a genetic perspective. In: Seagrasses: bology, ecology and conservation. Springer, Berlin. pp. 25-50.

Wernberg, T., M.S. Thomsen, F. Tuya, G.A. Kendrick, P.A. Staehr and B.D. Toohey. 2010. Decreasing resilience of kelp beds along a latitudinal temperature gradient: potential implications for a warmer future. Ecol. Lett. 13: 685-694. 
Wernberg, T., S. Bennett, R.C. Babcock, T. de Bettignies, K. Cure, M. Depczynski, F. Dufois, J. Fromont, C.J. Fulton, R.K. Hovey, E.S. Harvey, T.H. Holmes, G.A. Kendrick, B. Radford, J. Santana-Garcon, B.J. Saunders, D.A. Smale, M.S. Thomsen, C.A. Tuckett, F. Tuya, M.A. Vanderklift and S. Wilson. 2016. Climate-driven regime shift of a temperate marine ecosystem. Science 353: 169-172.

West, F., E. Cubero-Leon and C. Ciocan. 2016. Effects of environmental stressors affecting blue mussels Mytilus edulis Linnaeus, 1758 populations on the Sussex coast (UK). Vie Milieu 66: 219-226.

Willis, J.K. and J.A. Church. 2012. Regional sea-level projection. Science 336: 550-551.

Wolsak, S., D. Wingate and Q. Cronk. 2018. Environmental change in the terrestrial vegetation of Bermuda: Revisiting Harshberger (1905). Brittonia 70: 257-275.

Wood, K.A. and R.A. Stillman. 2014. Do birds of a feather flock together? Comparing habitat preferences of piscivorous waterbirds in a lowland river catchment. Hydrobiologia 738: 87-95.

WWF. 2015. Living blue planet report. In Gland, Switzerland.

Yesson, C., L.E. Bush, A.J. Davies, C.A. Maggs and J. Brodie. 2015. Large brown seaweeds of the British Isles: evidence of changes in abundance over four decades. Estuar. Coast. Shelf. Sci. 155: 167-175.

\section{Bionotes}

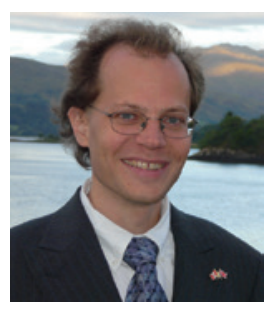

\section{Frithjof C. Küpper}

School of Biological Sciences, University of Aberdeen, Cruickshank Building, St Machar Drive, Aberdeen AB24 3UU, Scotland, UK, fkuepper@abdn.ac.uk

Frithjof C. Küpper has held the Chair in Marine Biodiversity at the University of Aberdeen (Oceanlab) since 2011. Over the past 25 years, he has studied the biodiversity and biochemistry of marine plants/algae - especially abiotic and biotic stress. He conducted graduate studies at Roscoff and Konstanz for a joint French-German Ph.D. His research resulted in the finding of iodide serving as an inorganic antioxidant in kelp, the first described from a living system, impacting atmospheric and marine chemistry.- A certified scientific diver, Frithjof has worked extensively in the South Atlantic (Ascension and Falkland Islands), but also in the Antarctic Peninsula and the Canadian Arctic for algal diversity-related projects.

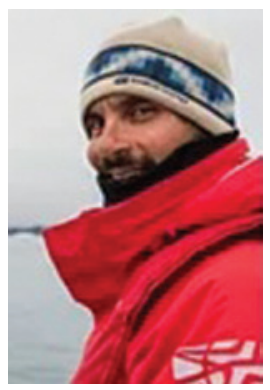

\section{Nicholas A. Kamenos}

School of Geographical and Earth Sciences, Gregory Building, University of Glasgow, Glasgow, G12 8QQ, Scotland, UK

Nicholas A. Kamenos research focusses on biogeochemical cycles in two broad groupings: (1) investigating relationships between global change (e.g. climate variability, ocean acidification and multiple stressors) and ecosystem engineers (e.g. coralline algae, corals and seagrass) along with the services they provide. Recently, this has focused on their role as blue carbon repositories. (2) the development of climatic and ecological proxies for the Holocene to better understand past responses of ecosystem engineers to different rates of environmental change. Both research groupings are strongly multidisciplinary including publications in journals ranging from Global Change Biology to PNAS to Geology. 